\title{
Analysis, forecasting, and management of indicators of the forest industry of the region
}

\author{
Olena Ovchynikova ${ }^{1, *}$ and Olha Dupliak ${ }^{1, * *}$ \\ ${ }^{1}$ Department of Automated Systems and Modeling in Economics, Khmelnytskyi National University, 11 Instytutska Str., Khmelnytskyi, \\ 29016, Ukraine
}

\begin{abstract}
The article considers the theoretical and methodological foundations of forest industry research. The analysis of indicators of the forest industry of Khmelnytskyi region and Ukraine is carried out. To do this, a list of indicators and methods of their collection for the study of the forest industry. Since the state of ecology and forestry in Ukraine is not in the best condition, it is objectively necessary to use methods of economic and mathematical modeling of forest management, which would take into account environmental, economic and social factors, which will quickly implement the principles of sustainable development in forest management. The dynamics of forestry indicators is estimated. Models of dynamics of indicators of forest branch are developed; the received forecasts are analyzed and recommendations on forest management in the region are given. It is determined that with an increase in investment in the development of the forest industry by $1 \%$, we can expect an increase in the volume of the logging market by 524632.5 points. The results of the study can serve as a basis for management decisions on the management of forestry indicators.
\end{abstract}

\section{Introduction}

Today, the domestic forest industry plays a significant role in the socio-economic life of society. At the same time, forest ecosystems perform a protective function of the environment, as well as designed to meet human ecological needs.

As the state of ecology and forestry in Ukraine is not in the best condition, it is objectively necessary to use methods of economic and mathematical modeling of forestry processes, which would take into account economic factors, which will quickly implement the principles of sustainable development in forestry [1].

The object of the study is the activities of forestry in Khmelnytskyi region and Ukraine.

The subject is theoretical, methodological and practical aspects of the effective functioning of forestry in the region, and economic and mathematical methods and models for forecasting forestry indicators.

The purpose of the study is to analyze the current state of forestry in Khmelnytskyi region and economic and mathematical forecasting to establish the dynamics and trends of the forest industry.

Prospects for the development of forestry and forestry activities largely depend on efficient and rationally organized forest management in accordance with modern requirements for economic activity. Forest resources should be considered as one of the main factors in ensuring the environmental, economic and social security of the region.

\footnotetext{
*e-mail: veleslavaovch@gmail.com

**e-mail: olgasvarychevska@gmail.com
}

\section{Literature review}

The problems of forest sector reform in recent years have gained unprecedented resonance due to the excessive interest of some political forces, businesses and NGOs in this segment of the national economy [2]. The forest theme became one of the main priorities of the economic program and a number of political parties, including parliamentary ones. Which began to create additional obstacles to the formation of modern forest policy aimed at ensuring continuous and inexhaustible forest use and increasing the impact of forestry and wood production on socio-economic the rise of the country and individual regions. Because of numerous political manipulations, promising areas of modernization of the forest management system do not receive adequate institutional support. Economic transformations in the country, which have been carried out for almost three decades in the forest sector, are accompanied by significant changes in the structure of domestic forestry, as well as affect the level of ecological and economic efficiency of forest use [3].

Theoretical and methodological bases of forest management, issues of efficiency of its functioning, assessment, complex use and restoration of forest resources are investigated in the works [4-14].

These works reflect research that contributes to the development of scientific understanding of the problems of organization of forestry production in general. Research [12] devoted to the study of management processes and environmental safety of forest resources of Ukraine. It is worth noting the work [9], in which the main attention is paid to the study of trends and the establishment of pat- 
terns of use of forest resources and the improvement of forest policy in Ukraine.

However, a number of issues related to the use and reproduction of forest resources and the formation of the information system of state support of forestry have not yet been properly reflected in scientific works.

Therefore, the effective functioning of the domestic forest industry implies the need for detailed economic and mathematical analysis in the context of sustainable development, further development requires forecasting of forest use taking into account the forest resource potential of individual regions.

The main tools for meeting information needs are forest inventory and monitoring [15]. Inventory provides a statistical assessment of resources, while monitoring assesses changes and identifies trends in the dynamics of the state of monitoring objects.

\section{Problem description and methodology}

In Ukraine, forest and wooded lands occupy about $17.6 \%$ (10.63 million hectares) of the total territory of the country 60.3 million hectares [16]. At the same time, the territory of Ukraine in comparison with many European countries is characterized by a low forest cover $(16.7 \%)$, which is calculated as a percentage of the area of forested forest areas to land area (figure 1).

\section{Number of harvested timber, th. M3}

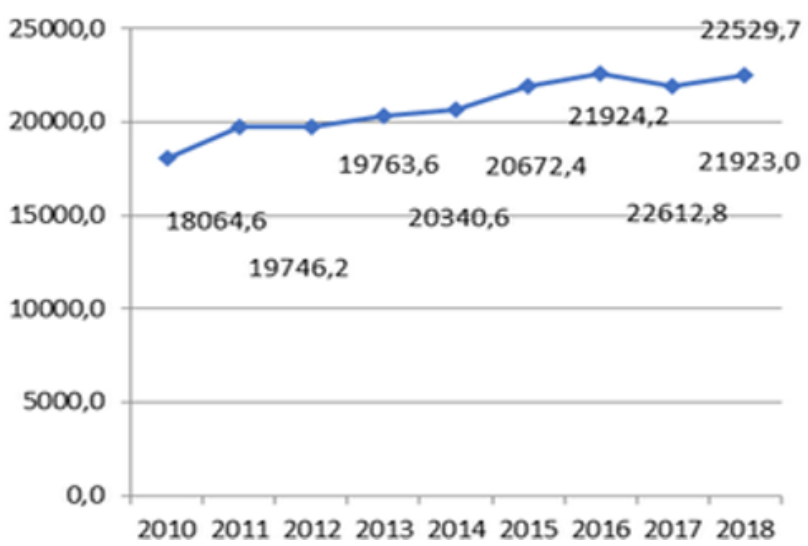

Figure 1. Dynamics of the amount of harvested wood

The problem of protecting forests from damage by pests and diseases remains difficult, as the general deterioration of the ecological situation in Ukraine has a negative impact on the condition of forests and reduces their natural resilience. In 2017, 2,371 fires were extinguished in the forests of subordinate enterprises on an area of 5,474 hectares, including 1,060 hectares on horseback.

This is 2.5 times more in number and 5 times in area compared to 2016. The average area of one fire doubled to 2.3 hectares. Losses from forest fires amounted to UAH 43.8 million. The main causes of fires $(82 \%)$ are human factors. The problem of illegal deforestation remains unresolved [17].
Therefore, the process of reforestation is important, although the dynamics of indicators of forest pest control in the plantations of the State Forestry Agency of Ukraine indicates insufficient implementation of a set of measures aimed at protecting forest ecosystems from pests.

Harvesting of wood in protected areas is carried out exclusively in order to take measures to prevent changes in natural complexes due to anthropogenic impact, preservation and restoration of plant communities, fire and sanitation measures, disaster relief.

The vast majority of care felling (68\% of the area) is carried out in operational forests [18]. The area on which pine and oak were harvested - in the Khmelnytskyi region in 2018 also has the largest share (figures 2, 3).

\section{The area on which timber was harvested}

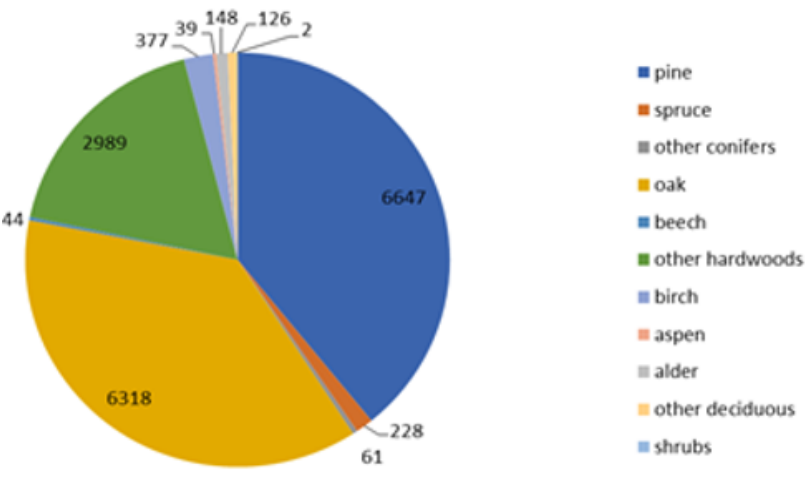

Figure 2. Harvesting of wood according to the species composition of stands in 2018

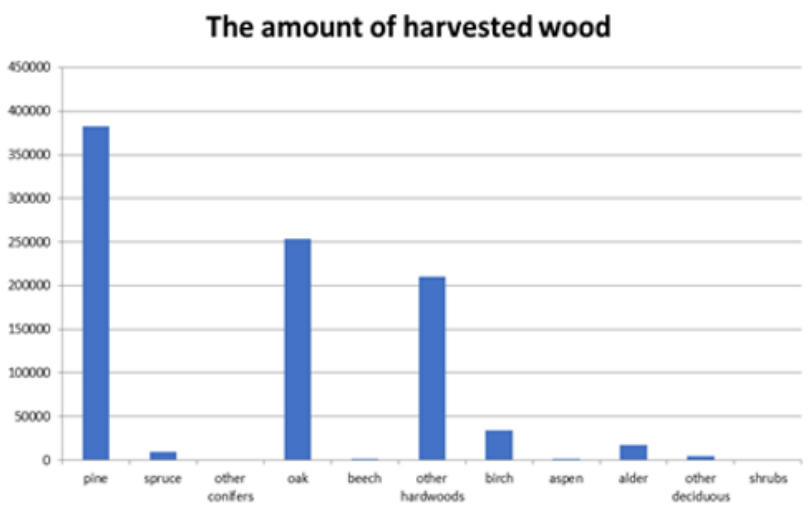

Figure 3. The amount of harvested wood by species composition in 2018

To bring the forests to the proper sanitary condition in the damaged plantations, measures are taken to improve the sanitary condition of forests.

Appropriate funding is also needed for the sustainable development $[10,11,19,20]$, and in particular, in the forest industry [21-23]. However, no funds have been provided for the financing of forestry and hunting activities for the last two years - analyzing the dynamics of financial support of the state, which had a growing trend in 2000, and since 2016 the funding of forestry and hunting tasks 
and measures from the state budget has been stopped (figure 4).

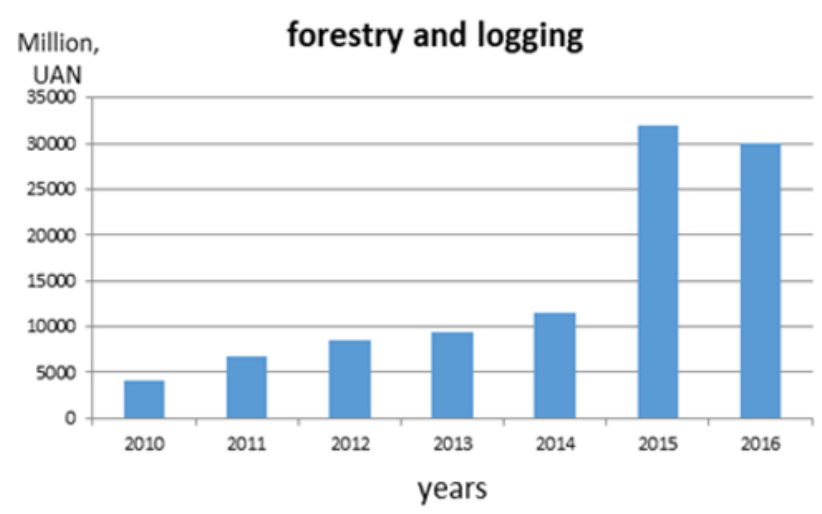

Figure 4. Capital investments in forestry and logging in Khmelnytskyi region

In modern conditions, the process of forestry research should reach a qualitatively new level - in particular, it is necessary to develop new approaches to the application of econometric models and methods for forecasting indicators at the regional level.

\section{Findings}

Statistical information describing the processes of the past years is used for forecasting, and the trends of changes in macroeconomic indicators are assessed by different methods. The following information was used to forecast the forestry indicators of Khmelnytskyi region (table 1) [18].

Table 1. Initial information for forecasting forest indicators

\begin{tabular}{lllllll}
\hline$t$ & Years & $Y_{1}$ & $Y_{3}$ & $Y_{2}$ & $Y_{4}$ & $Y_{5}$ \\
\hline 1 & 2013 & 1432 & 3095 & 596933 & 372308 & 9324 \\
2 & 2014 & 1650 & 3156 & 615524 & 391478 & 11593 \\
3 & 2015 & 1848 & 3690 & 698566 & 455775 & 31975 \\
4 & 2016 & 2016 & 3961 & 750549 & 487522 & 29955 \\
5 & 2017 & 1817 & 6624 & 781993 & 501765 & 33305 \\
6 & 2018 & 1540 & 6577 & 836566 & 413171 & 37977 \\
\hline
\end{tabular}

As there has been no capital investment in the forest industry for the last two years, we decided to forecast this indicator and use the forecast data in further forecasts, where

$Y_{1}$ - Forest reproduction area, hectares;

$Y_{2}$ - Logging by types of forestry products, business round wood, $\mathrm{m}^{3}$;

$Y_{3}$ - Area of foci of forest pests and diseases eliminated by control measures and under the influence of natural factors, hectares;

$Y_{4}$ - The number of manufactured forestry products, Fuel wood, $m^{3}$;

$Y_{5}$ - Capital investments in forestry, thousand UAH.

This approach allows taking into account the nonlinear nature of the studied characteristic, in this case, the economic development level, as well as to investigate changes in the structure of the objects under study by the values of the comprehensive index calculated for different periods.
Table 2. The results of forecasting by the method of the average annual growth rate

\begin{tabular}{llllll}
\hline \multicolumn{7}{c}{$Y_{1}$} & $Y_{2}$ & $Y_{3}$ & $Y_{4}$ & $Y_{5}$ \\
\hline$k-p$ & 1,06 & 1,10 & 1,20 & 1,08 & 1,38 \\
\hline$Y_{n+1}$ & 1928,44 & 836608 & 8012 & 540629,7 & 45786,4 \\
$Y_{n+2}$ & 2046,7 & 895038 & 9691 & 582504,6 & 62945,3 \\
$Y_{n+3}$ & 2172,3 & 957549 & 11721 & 627623,0 & 86534,6 \\
\hline
\end{tabular}

Table 3 presents the results of forecasting by the method of average absolute growth.

Table 3. The results of forecasting by the method of the average annual growth rate

\begin{tabular}{llllll}
\hline & $Y_{1}$ & $Y_{2}$ & $Y_{3}$ & $Y_{4}$ & $Y_{5}$ \\
\hline$\Delta-y$ & 96,3 & 46265 & 5995,3 & 882,3 & 32364,3 \\
\hline \multicolumn{5}{c}{ Forecast } \\
\hline$Y_{n+1}$ & 1913,3 & 828258 & 7506 & 534129,3 & 39300,3 \\
$Y_{n+2}$ & 2009,5 & 874523 & 8389 & 566493,5 & 45295,5 \\
$Y_{n+3}$ & 2105,8 & 920788 & 9271 & 598857,8 & 51290,6
\end{tabular}

Table 4 presents the results of forecasting the indicators of the forest industry by extrapolation based on the moving average.

Table 4. The results of forecasting by the method of average absolute growth

\begin{tabular}{llllll}
\hline & $Y_{1}$ & $Y_{2}$ & $Y_{3}$ & $Y_{4}$ & $Y_{5}$ \\
\hline$\Delta x_{t}$ & -199 & 31444 & 2663 & 14243 & 3350 \\
$\Delta x_{t-1}$ & 168 & 51983 & 271 & 31747 & - \\
& & & & 2020 \\
$\Delta x_{t-2}$ & 198 & 83042 & 534 & 64297 & 20382 \\
\hline \multicolumn{5}{c}{ Forecast } \\
\hline$Y_{n+1}$ & 1812,8 & 800730,2 & 7227,7 & 513121,6 & 35062,7 \\
$Y_{n+2}$ & 1795,4 & 813936,9 & 7795,9 & 520196,1 & 35463,0 \\
$Y_{n+3}$ & 1755,7 & 820219,4 & 8328,0 & 523041,8 & 36132,3 \\
\hline
\end{tabular}

Another method of forecasting is the FORECAST function. Table 5 shows the calculations of forecasts using this function.

However, for completeness of the analysis it is necessary not only to receive forecast values, but also to estimate, how much they are exact, that is, what error of the received results. To do this, use the ex post method.

For the indicator "Forest reproduction area" the best method of forecasting was the FORECAST function method, which gave only $9.6 \%$ error, and the worst - the method of average annual growth rate, which erred by $25.5 \%$, as well as the method of average absolute growth, which gave an error of $24.2 \%$ (table 6). For the indicator "Logging by types of forestry products" the best was the method of average annual growth rate, which showed a deviation of only $0.005 \%$, and the worst - the method of FORECAST function (6.1\%). In general, for this indicator, all methods have an error of less than $10 \%$, all methods can be used for further analysis (table 7). 
Table 5. The results of forecasting by the method of average absolute growth

\begin{tabular}{llllll}
\hline Years & $Y_{1}$ & $Y_{2}$ & $Y_{3}$ & $Y_{4}$ & $Y_{5}$ \\
\hline 2010 & 2402 & 576092 & 3412 & 353913 & 4150 \\
2011 & 1972 & 616736 & 4353 & 400612 & 6821 \\
2012 & 1539 & 570052 & 5418 & 369453 & 8495 \\
2013 & 1432 & 596933 & 3095 & 372308 & 9324 \\
2014 & 1650 & 615524 & 3156 & 391478 & 11593 \\
2015 & 1848 & 698566 & 3690 & 455775 & 31975 \\
2016 & 2016 & 750549 & 3961 & 487522 & 29955 \\
2017 & 1817 & 781993 & 6624 & 501765 & 33305 \\
2018 actual meanings & 1540 & 836566 & 6577 & 413171 & 37977 \\
2018 forecast & 1688,25 & 785511,3 & 4949,346 & 510227,4 & 37977,04 \\
2019 forecast & 1589,861 & 838136,8 & 5559,198 & 486121,9 & 43917,21 \\
2019 forecast & 1679,077 & 883086 & 5785,881 & 514158,9 & 50157,08 \\
\hline
\end{tabular}

Table 6. Estimation of the error of forecasting methods for the indicator "Forest reproduction area"

\begin{tabular}{|c|c|c|c|c|}
\hline $\begin{array}{l}\text { Actual } \\
\text { value }\end{array}$ & $\begin{array}{l}\text { Forecast } \\
\text { for } 2018\end{array}$ & $\begin{array}{l}\text { Absolute } \\
\text { deviation }\end{array}$ & $\begin{array}{l}\text { Relative } \\
\text { devi- } \\
\text { ation, } \\
\%\end{array}$ & $\begin{array}{l}\text { Forecasting } \\
\text { method }\end{array}$ \\
\hline \multirow{5}{*}{1540} & 1913,2500 & $-373,25$ & $-24,2$ & $\begin{array}{l}\text { Average } \\
\text { absolute } \\
\text { increase }\end{array}$ \\
\hline & 1928,4479 & $-388,44788$ & $-25,2$ & $\begin{array}{l}\text { Average } \\
\text { annual }\end{array}$ \\
\hline & & & & $\begin{array}{l}\text { growth } \\
\text { rate }\end{array}$ \\
\hline & 1812,8042 & $-272,8042$ & $-17,7$ & $\begin{array}{l}\text { Flowing } \\
\text { average } \\
\text { method }\end{array}$ \\
\hline & 1688,25 & $-148,25$ & $-9,6$ & PREDICTI \\
\hline
\end{tabular}

Table 7. Error estimation of forecasting methods for the indicator "Logging by types of forestry products"

\begin{tabular}{|c|c|c|c|}
\hline $\begin{array}{l}\text { Actual Forecast } \\
\text { value }\end{array}$ & $\begin{array}{l}\text { Absolute } \\
\text { deviation }\end{array}$ & $\begin{array}{l}\text { Relative } \\
\text { devi- } \\
\text { ation, } \\
\text { per }\end{array}$ & $\begin{array}{l}\text { Forecasting } \\
\text { method }\end{array}$ \\
\hline \multirow[b]{3}{*}{836566} & 8308 & 1,0 & $\begin{array}{l}\text { Average } \\
\text { absolute } \\
\text { increase }\end{array}$ \\
\hline & $-42,33$ & 0,005 & $\begin{array}{l}\text { Average } \\
\text { annual }\end{array}$ \\
\hline & & & $\begin{array}{l}\text { growth } \\
\text { rate }\end{array}$ \\
\hline 800730,24 & 35835,756 & 4,3 & $\begin{array}{l}\text { Flowing } \\
\text { average } \\
\text { method }\end{array}$ \\
\hline 785511,3 & 51054,7 & 6,1 & PREDICTIC \\
\hline
\end{tabular}

For the indicator "Capital investment in forestry" we calculated the value for 2018 instead of the missing one, then the FORECAST function itself cannot be estimated. And among others, the best is the average absolute in- crease $(3.5 \%$ error). The method of the average annual growth rate $(20.6 \%)$ turned out to be the worst.

Table 8. Estimation of forecasting error for the indicator "Capital investment in forestry"

\begin{tabular}{|c|c|c|c|}
\hline $\begin{array}{l}\text { Actual Forecast } \\
\text { value }\end{array}$ & $\begin{array}{l}\text { Absolute } \\
\text { deviation }\end{array}$ & $\begin{array}{l}\text { Relative } \\
\text { devi- } \\
\text { ation, } \\
\text { per }\end{array}$ & $\begin{array}{l}\text { Forecasting } \\
\text { method }\end{array}$ \\
\hline 39300,2500 & $-1323,25$ & $-3,5$ & $\begin{array}{l}\text { Average } \\
\text { absolute } \\
\text { increase }\end{array}$ \\
\hline 45786,3719 & $-7809,3719$ & $-20,6$ & $\begin{array}{l}\text { Average } \\
\text { annual }\end{array}$ \\
\hline 37977 & & & $\begin{array}{l}\text { growth } \\
\text { rate }\end{array}$ \\
\hline 35062,7072 & 2914,2928 & 7,7 & $\begin{array}{l}\text { Flowing } \\
\text { average } \\
\text { method }\end{array}$ \\
\hline 37977,04 & $-0,04$ & 0,0 & PREDICTI \\
\hline
\end{tabular}

Table 9 shows the estimation of the forecast error of the indicator "Area of foci of forest pests and diseases eliminated by control measures and under the influence of natural factors". For this indicator, the best method was the current average $(9.9 \%$ error), and the worst - the FORECAST function $(24.7 \%)$ and the method of the average annual growth rate $(21.8 \%)$.

Table 10 contains the estimation of forecasting of the indicator "Quantity of the made production of forestry". As can be seen for this indicator, all methods gave an error of more than $10 \%$, so the methods of simple extrapolation can not accurately predict the behavior of it.

Consider another method of forecasting - a trendbased extrapolation. To determine the trend, it is enough to build a graph for the values of the studied indicator and on the basis of it to draw a conclusion about the nature of their change.

Figure 5 shows the trend models for the indicator "Forest reproduction area".

The quality of the selected model is evaluated by the value of the coefficient of determination: the closer it is to one, the better the model. As can be seen from the graph, 
Table 9. Estimation of the error of forecasting methods for the indicator "Area of foci of forest pests and diseases eliminated by control measures and under the influence of natural factors"

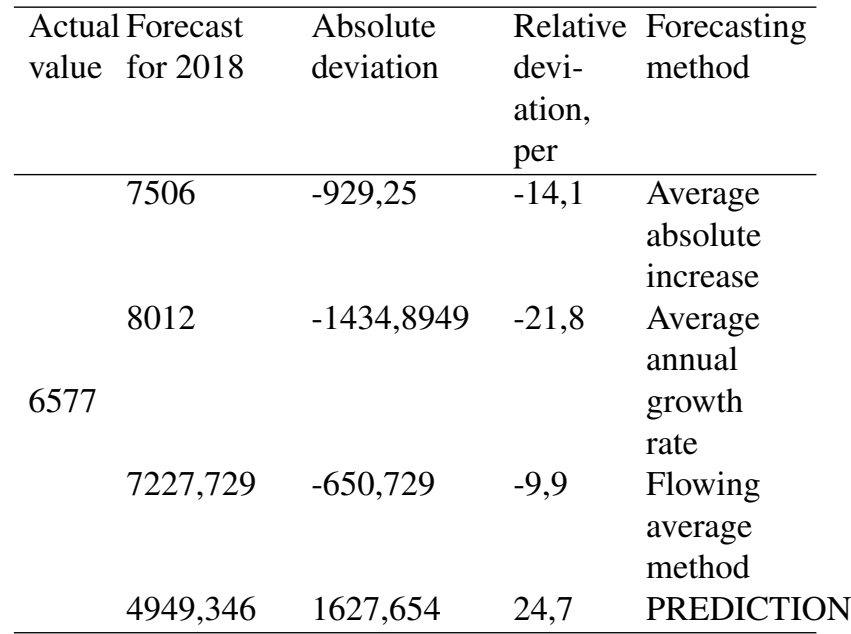

Table 10. Estimation of forecasting error for the indicator "Quantity of forestry products"

\begin{tabular}{|c|c|c|c|}
\hline $\begin{array}{l}\text { Actual Forecast } \\
\text { value }\end{array}$ & $\begin{array}{l}\text { Absolute } \\
\text { deviation }\end{array}$ & $\begin{array}{l}\text { Relative } \\
\text { devi- } \\
\text { ation, } \\
\text { per }\end{array}$ & $\begin{array}{l}\text { Forecasting } \\
\text { method }\end{array}$ \\
\hline 534129,25 & $-120958,25$ & $-29,30$ & $\begin{array}{l}\text { Average } \\
\text { absolute } \\
\text { increase }\end{array}$ \\
\hline 540629,65 & $-127458,65$ & $-30,80$ & $\begin{array}{l}\text { Average } \\
\text { annual } \\
\text { growth } \\
\text { rate }\end{array}$ \\
\hline 513121,63 & $-99950,63$ & $-24,20$ & $\begin{array}{l}\text { Flowing } \\
\text { average } \\
\text { method }\end{array}$ \\
\hline 510227,40 & $-97056,40$ & $-23,50$ & PREDICTI \\
\hline
\end{tabular}

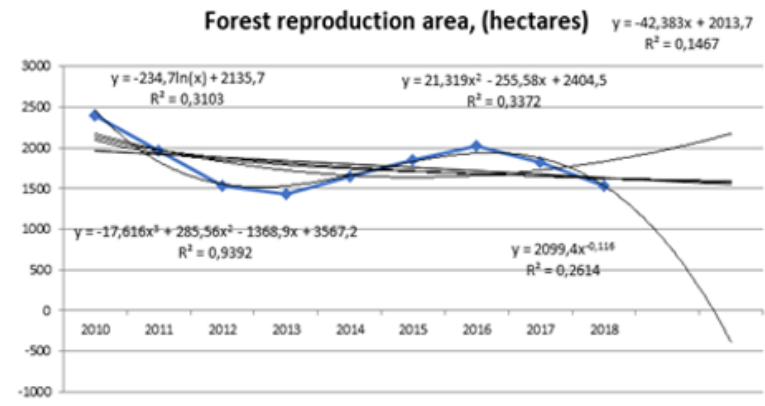

Figure 5. Trend models of the indicator "forest reproduction area" in Khmelnytskyi region

the dynamics of the indicator does not have a clear trend, so the trend models have a small coefficient of determination.

Table 11 shows that only a polynomial of the third degree was able to reflect trends with a high coefficient of determination $(0,93)$, so only it can be used for forecasting.

Figure 6 shows the trend models for the indicator Area of pests and forest diseases, eliminated by control measures and under the influence of natural factors. This indicator also does not have a clear trend.

\section{Area of foci of forest pests and diseases eliminated by control measures and under the influence of natural factors, (hectares)}

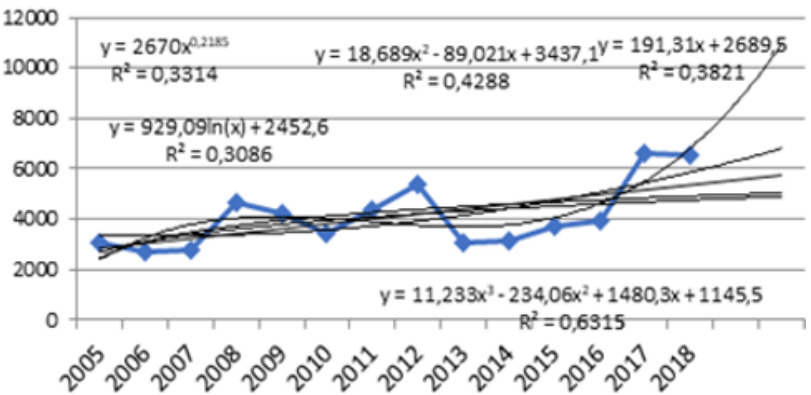

Figure 6. Trend models of the indicator "Area of foci of forest pests and diseases eliminated by control measures and under the influence of natural factors" in Khmelnytskyi region

Figure 7 shows the graph and trend equation for the indicator "Logging by type of forestry products, business roundwood". This indicator has a fairly pronounced dynamics, almost all trend lines have a coefficient of determination greater than 0,6 . Therefore, all the obtained trend models can be used for further analysis.

Logging by types of forestry products, business round wood,

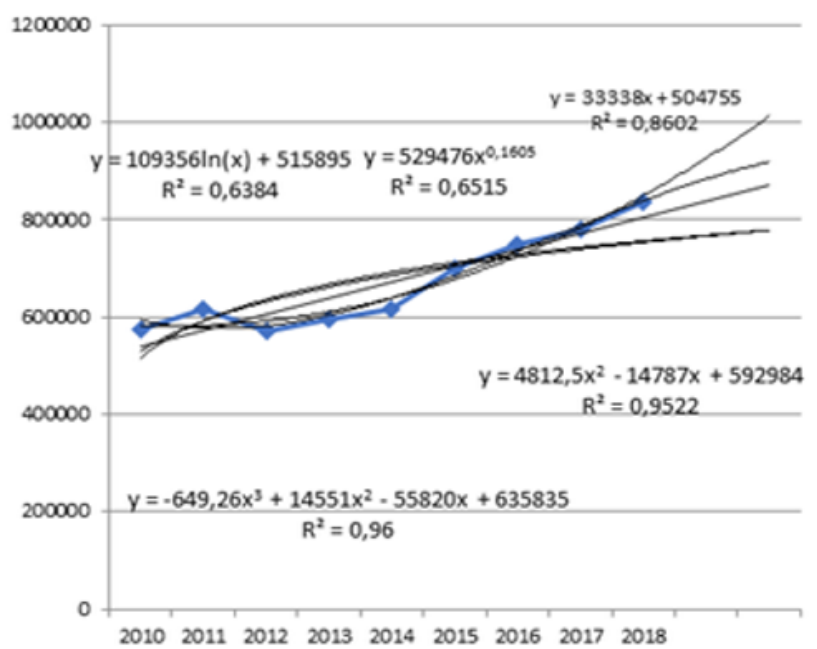

Figure 7. Trend models of the indicator "Logging by types of forestry products, business roundwood"

Figure 8 shows the dynamics and modeling of the indicator "The number of manufactured forestry products, fuel wood". The indicator of fuel wood production in the Khmelnytskyi region had a good trend line until 2017, and in 2018 decreased. 
Table 11. Trend models and forecast for 2018 of the indicator "Forest reproduction area"

\begin{tabular}{lllll}
\hline № & Type of dependence & Equation & $\begin{array}{l}\text { Coefficient } \\
\text { of determi- } \\
\text { nation }\end{array}$ & $\begin{array}{l}\text { Forecast for } \\
2018\end{array}$ \\
& & & $\mathrm{R}^{2}=0,1467$ & - \\
\hline 1 & Linear & $y=-42,383 x+2013,7$ & $\mathrm{R}^{2}=0,9392$ & 1535,396 \\
2 & Polynomial of the third degree & $y=-17,616 x^{3}+285,56 x^{2}-1368,9 x+3567,2$ & $\mathrm{R}^{2}=0,3372$ & - \\
3 & Polynomial of the second degree & $y=21,319 x^{2}-255,58 x+2404,5$ & $\mathrm{R}^{2}=0,3103-$ \\
4 & Logarithmic & $y=-234,7 \ln (x)+2135,7$ & $\mathrm{R}^{2}=0,2614-$ \\
\hline & Staid & $y=2099,4 x-0,116$ &
\end{tabular}

It is because of this decrease that we can see that not all models have clearly continued the trend, but all models predict an increase in this figure in the future. The coefficient of determination of the obtained trend models showed a high value, more than 0,6 - only in the case of a polynomial of the third degree. Therefore, for this indicator only this model can be used for analysis.

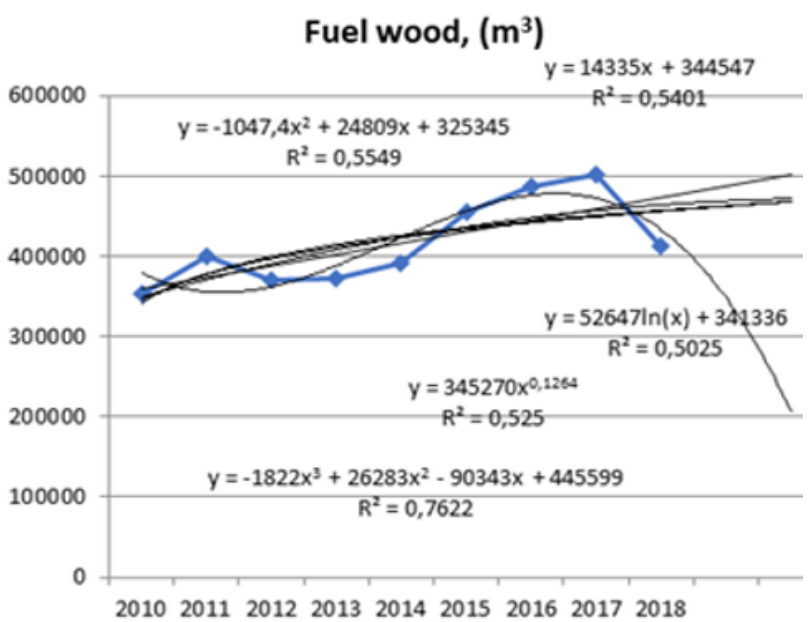

Figure 8. Trend models of the indicator "Logging by types of forestry products, business roundwood"

Table 12 calculates the forecasts of the indicator $x_{1}-$ Capital investment in forestry according to trend model, where

$Y_{1}-$ Forest reproduction area, hectares;

$Y_{2}$ - Logging by types of forestry products, business round wood, $\mathrm{m}^{3}$;

$Y_{3}$ - Area of foci of forest pests and diseases eliminated by control measures and under the influence of natural factors, hectares;

$Y_{4}$ - The number of manufactured forestry products, Fuel wood, $m^{3}$;

$Y_{5}$ - Capital investments in forestry, thousand UAH.

Thus, we have developed forecasts of the main indicators of forestry in Khmelnytskyi region by simple extrapolation. Not all methods showed a qualitative result. The ex post method was used to estimate the forecast, which made it possible to estimate the forecasting error on the actual data for 2018. As can be seen from the forecasting analysis, not all time series of forest industry indicators have a clear trend, which can be estimated by forecasting extrapolation. Thus, the best trend is in the indicator "Logging by types of forestry products", its time series quite clearly reflects the constant increase in the indicator. So, it is for this indicator that our forecasts turned out to be the most accurate.

Correlation-regression method can also be used to predict the development of key indicators of forestry in Khmelnytskyi region . For modeling we will use the indicator $Y$ - Logging by types of forestry products, business round wood, $m^{3}$, and $x_{1}$ - Capital investments in forestry, thousand UAH (table 13).

The main factor in the development of the forest products market during 2013 to 2018 was the volume of investment in forestry, which is confirmed by the study of correlations (table 14).

Based on the initial data, we build a regression model, starting with the assessment of the quality of modeling, which is shown in table 15. As can be seen from the table, the model of the impact of the amount of investment on logging showed a high correlation between the factor and the result.

The tabular value of the Fisher criterion is 5,98, so the obtained value of the Fisher criterion is greater than the tabular, which indicates the adequacy of the model.

The regression coefficients were obtained by the method of least squares (table 15). Based on the results of correlation-regression analysis, a model of the form (1) was constructed:

$$
Y=524632,5 * x_{1}+7,346678
$$

where $Y$ - Logging by type of forestry products, business roundwood, $m^{3}, x_{1}$ - Capital investments in forestry, (thousand UAH).

Thus, with an increase in investment in the development of the forest industry by $1 \%$, we can expect an increase in the volume of the logging market by 524632.5 points.

So, if we forecast logging according to the obtained model, we will get $864976.6 \mathrm{~m}^{3}$ of roundwood logging in 2019 and $901939.1 \mathrm{~m}^{3}$ in 2020.

Table 16 presents the empirical data obtained from the model, which for clarity. As can be seen from the figure, the values obtained for the model are almost indistinguishable from the actual ones, which once again confirms the quality of the simulation.

Table 17 presents all the forecasts obtained for this indicator. 
Table 12. Results of forecasting

\begin{tabular}{llllll}
\hline Years & $Y_{1}$ & $Y_{2}$ & $Y_{3}$ & $Y_{4}$ & $Y_{5}$ \\
\hline 2010 & 2402 & 576092 & 3412 & 353913 & 4150 \\
2011 & 1972 & 616736 & 4353 & 400612 & 6821 \\
2012 & 1539 & 570052 & 5418 & 369453 & 8495 \\
2013 & 1432 & 596933 & 3095 & 372308 & 9324 \\
2014 & 1650 & 615524 & 3156 & 391478 & 11593 \\
2015 & 1848 & 698566 & 3690 & 455775 & 31975 \\
2016 & 2016 & 750549 & 3961 & 487522 & 29955 \\
2017 & 1817 & 781993 & 6624 & 501765 & 33304,86 \\
2018 actual meanings & 1540 & 836566 & 6577 & 413171 & 37977,04 \\
2018 forecast & 1688,25 & 785511,3 & 4949,346 & 510227,4 & 37977,04 \\
2019 forecast & 1589,861 & 838136,8 & 5559,198 & 486121,9 & 43917,21 \\
2020 forecast & 1679,077 & 883086 & 5785,881 & 514158,9 & 50157,08 \\
\hline
\end{tabular}

Table 13. Source information for modeling

\begin{tabular}{lll}
\hline Years & $Y$ & $x_{1}$ \\
\hline 2013 & 596933 & 9324 \\
2014 & 615524 & 11593 \\
2015 & 698566 & 31975 \\
2016 & 750549 & 29955 \\
2017 & 781993 & 33305 \\
2018 & 836566 & 37977 \\
\hline
\end{tabular}

Table 14. Matrix of the pairwise correlation coefficient

\begin{tabular}{lll}
\hline & $Y$ & $x_{1}$ \\
\hline$Y$ & 1 & 0,941776 \\
$x_{1}$ & 0,941776 & 1 \\
\hline
\end{tabular}

Table 15. Regression statistics

\begin{tabular}{ll}
\hline Multiple R & 0,941776 \\
\hline R-square & 0,886942 \\
Normalized R-square & 0,858677 \\
Standard error & 35512,55 \\
Observation & 6 \\
\hline
\end{tabular}

Table 16. Predicted values

\begin{tabular}{llll}
\hline Observation & Provided by $Y$ & Leavings & $\begin{array}{l}\text { Standard } \\
\text { balances }\end{array}$ \\
\hline 1 & 593132,9 & 3800,10 & 0,1196 \\
2 & 609802,5 & 5721,47 & 0,1801 \\
3 & 739542,5 & $-60976,50$ & $-1,9197$ \\
4 & 744702,2 & 5846,78 & 0,1841 \\
5 & 789313,6 & 12679,41 & 0,3992 \\
6 & 853637,3 & 32928,73 & 1,0367 \\
\hline
\end{tabular}

Thus, the study showed that the development trend of forestry indicators is problematic and requires increased attention to management.

Studies have shown that the main factor influencing the development of the logging market is the financing of this industry, so it is necessary to pay attention to investment growth. First of all, it should be domestic investments and means of state regulation. One of the chosen ways is the one voted in the Verkhovna Rada and received the status of the Law of Ukraine "On Amendments to Certain Legislative Acts of Ukraine to Strengthen Forest Protection, Prevent Fires on Forest and Water Fund Lands, Peatlands and Other Categories".

Now it is necessary to act ahead, to carry out active explanatory work among the population. it is necessary to appeal to the representatives of the central executive bodies to do everything possible within their powers to prevent the possible consequences of inadequate use of forest resources. To instruct the heads of territorial bodies to apply preventive measures, including the elimination of natural dumps, sewage treatment, etc.

As stated in [23], the study of theoretical and practical features of the functioning of forestry requires additional research to determine the place of forestry in the system of the entire national economy, its impact on the development of the state economy. Further research in this area is to analyze specific species sources of forestry financing, determining the effectiveness of investments and the rationality of their use.

\section{Conclusions}

Forestry is one of the important areas of territorial development. It is very difficult to predict the natural phenomena with a high degree of probability, which is confirmed by the data of previous years [24]. In this regard, in the future it is planned to improve methods of preventive work, increase responsibility for violating safety rules, restrict unorganized recreation and access of vehicles to the forest fund during the growing season.

As stated in [12], "Forests also are central to maintaining the environmental commons. Nearly $90 \%$ of terrestrial biodiversity is found in the world's forests, with a disproportionate share in the forests of developing countries. Most of the carbon emissions of developing countries come from deforestation, which accounts for between $10 \%$ and $30 \%$ of global carbon emissions. Unfortunately, the lack of markets for the national and global environmental services offered by forests has contributed to high rates of deforestation in developing countries. Growing forests are a valuable resource not just for their timber and biodiversity values but also for their prospective value if a 
Table 17. Forecast of roundwood logging, $m^{3}$

\begin{tabular}{|c|c|c|c|c|c|c|}
\hline Year & $\begin{array}{l}\text { Regression } \\
\text { model }\end{array}$ & $\begin{array}{l}\text { Trend model } \\
\text { (best) }\end{array}$ & $\begin{array}{l}\text { The method is } \\
\text { average annual } \\
\text { growth rate }\end{array}$ & $\begin{array}{l}\text { The method is } \\
\text { the average ab- } \\
\text { solute increase }\end{array}$ & $\begin{array}{l}\text { Extrapolation } \\
\text { based on } \\
\text { the flowing } \\
\text { average }\end{array}$ & FORECAST \\
\hline 2019 & 864976 & 939295 & 895038 & 874523 & 813937 & 838136 \\
\hline 2020 & 901939 & 1029961 & 957549 & 920788 & 820219 & 883086 \\
\hline
\end{tabular}

global market emerges for the sequestering of carbon from forests".

Thus, the article develops forecasts of indicators of the forest industry of Khmelnytskyi region. These calculations can be used to carry out measures aimed at improving the efficiency of forestry.

The main directions of solving the problems of forest complex development (forestry and timber industries) are:

- improvement of forms of management of this complex;

- integrated use of available wood resources (own and imported);

- increasing financing and efficiency of investments in the forestry sector;

- intensification of forest reproduction and forest use.

In the current situation in our country, the decisive factor is the choice of forms of organization of production in integrated enterprises, including - ensuring the implementation of basic principles of forest reproduction, forest use, efficient processing of forest resources.

Continuation of scientific research on this issue will help further development of national forestry.

\section{References}

[1] J.P. Kimmins, Forest ecology: A Foundation for Sustainable Forest Management and Environmental Ethics in Forestry (Prentice Hall, Saddle River, New York, NY, 2003)

[2] A. Lysychko, Problems of theory and methodology of accounting, control and analysis pp. 74-82 (2018)

[3] L. Saharnatskaya, Bulletin of Sumy National Agrarian University. Series: Economics and Management 2, 116 (2015)

[4] M. Shershun, Balanced nature using 1, 5 (2013)

[5] O.I. Drebot, M. Shershun, O. Shkuratov, Zbalansovanyi rozvytok lisovoho sektoru ekonomiky v konteksti yevropeiskoi intehratsii Ukrainy (Balanced development of the forest sector of the economy in the context of Ukraine's European integration) (Ahrarna nauka, Kyiv, 2014)

[6] O.V. Sakal, Efektyvne upravlinnia zemliamy lisohospodars'koho pryznachennia (Effective management of land for forestry purposes) (State Institution 'Institute of Economics of Nature Management and Sustainable Development of the National Academy of Sciences of Ukraine', Kyiv, 2012)

[7] O.I. Furdychko, Ekonomika Ukrainy 5, 56 (2013)
[8] E. Dhimitri, A. Gabeta, M. Bello, The USV Annals of Economics and Public Administration 15, 51 (2015)

[9] Y. Mishenin, I. Kobylianska, T. Usik, I. Yarova, Ekolohooriientovane lohistychne upravlinnia vyrobnytstvom (Eco-oriented logistics production management) (Papirus, Sumy, 2013)

[10] P. Hryhoruk, N. Khrushch, S. Grygoruk, E3S Web of Conferences 166, 13023 (2020)

[11] P. Hryhoruk, N. Khrushch, S. Grygoruk, Assessing the Investment Capacity of the Agricultural Sector: Case of Ukraine, in Proceedings of the 2020 10th International Conference on Advanced computer information technologies ASIT'2020 (Deggendorf, 2020), pp. 183-187

[12] M. Dubyna, O. Zinkevych, Business Inform 2, 187 (2020)

[13] M. Selinnyi, O. Korma, Modern Economics 17, 211 (2019)

[14] B. Solberg, K. Rykowski, Forest Policy Review and Strategy Development: Analytical Studies (The World Bank, Washington, DC, 2000)

[15] V. Zhulkanych, Osnovni pryntsypy $i$ zavdannia staloho upravlinnia lisamy rehionu $v$ systemi ratsionalnoho pryrodokorystuvannia (Basic principles and tasks of sustainable forest management of the region in the system of rational nature management), in Proceedings of the International scientific-practical conference on The ecological, socio-economic and historical-cultural aspects of the Maramures border region development, edited by F.D. Hamor (FOP Petryshyn, Khmelnytskyi, 2016), pp. 131-134, http://cbr.nature.org. $\mathrm{ua} / \mathrm{conf2016/Pr \_ 2016.pdf}$

[16] Derzhavne ahentsvo lisovykh resursiv Ukrainy (Sstate agency of forest resources of Ukraine) (2020), http://dklg.kmu.gov.ua/forest/ control/uk/index

[17] V. Doskich, Ekolohichne lykho: Vynyshchennia lisiv $v$ Ukraini (environmental disaster: Deforestation in Ukraine) (2015), https: //cutt . ly/SbjbHM5

[18] Derzhavna sluzhba statystyky Ukrainy (State statistics service of Ukraine) (2020), http://www. ukrstat.gov.ua/

[19] P. Hryhoruk, N. Khrushch, S. Grygoruk, IOP Conference Series: Earth and Environmental Science 628, 012026 (2021)

[20] M. Nehrey, A. Kaminskyi, M. Komar, Periodicals of Engineering and Natural Sciences 7, 702 (2019) 
[21] I.I. Kychko, Y.O. Harus, Global and national economic problems 11, 128 (2016)

[22] O. Iaremko, Efektyvna ekonomika 11 (2016)
[23] S. Makarenko, Efektyvna ekonomika 12, 73 (2018)

[24] O. Ovchynnikova, O. Dupliak, O. Khan, E3S Web of Conferences 166, 13004 (2020) 